\section{Long term follow-up of a large patient population with stage 2 and 3 esophageal cancer}

\author{
Diana M Christensen*, Anna K Paulsson, Balkarn S Thind, \\ Trevor T Miller, Jing Zeng and Shilpen A Patel
}

MD, Department of Radiology, University of Washington, USA
Received: 07 July, 2020

Accepted: 15 July, 2020

Published: 17 July, 2020

*Corresponding author: Diana M Christensen, MD, Department of Radiology, University of Washington, 11244 Greenwood Ave N \#1-303, Seattle, WA 98133, USA, Tel: 208-841-1308; Fax: 206-598-6218;

E-mail: Dmc48@uw.edu

Keywords: Esophageal cancer; Trimodality therapy; Chemoradiation; Neoadjuvant therapy

https://www.peertechz.com

Check for updates

\begin{abstract}
Objectives: Patients with stage II and III esophageal cancer are often incurable with surgery alone, suggesting the importance of optimizing other treatments such as chemotherapy and radiation. This retrospective analysis compared the survival and treatment-related toxicities of esophageal cancer patients receiving trimodality therapy to two other common clinical regimens.
\end{abstract}

Methods: Patients with stage II or III esophageal carcinoma who presented for treatment between 1995 and 2016 were eligible for inclusion. Median overall and disease-free survival (DFS) was calculated and compared between those who received Trimodality therapy (T), Surgery alone (S), or Chemoradiation alone (CH + R).

Results: This analysis included 358 patients. Median overall survival for T patients was superior $(42.8$ months, $\mathrm{p}<0.001)$ compared to those in the $\mathrm{CH}+\mathrm{R}(21.5$ months) and S groups (19.3 months). $\mathrm{CH}+\mathrm{R}$ patients had the greatest DFS of 21 months, followed by $\mathrm{T}$ with 15.5 months, though this difference was not significant $(p=0.56)$. Patient gender $(p<0.036)$ and treatment toxicity $(p<0.002)$ had significant effects on outcome. Median follow-up time for all patients was 22 months (range $1-250 \mathrm{mos})$.

Conclusions: Though five-year overall survival rates for esophageal cancer patients remain close to $20 \%$, neoadjuvant chemoradiation may improve outcomes. This large study with long follow-up demonstrates that patients can be selected for appropriate therapy. Our results suggest that patients receiving trimodality therapy have a higher median overall survival without increased treatment-related toxicity. This data may help guide clinical decision-making and patient selection to improve the survival of patients with advanced esophageal cancer.

\section{Introduction}

Esophageal carcinoma is the sixth deadliest cancer worldwide, currently affecting more than 450,000 individuals [1]. In the United States, approximately 16,000 deaths occur each year. The incidence of esophageal cancer continues to rise for unclear reasons and cure rates remain low, with fewer than $20 \%$ of patients surviving 5 years after diagnosis [2].

The generally poor outcomes in the management of esophageal carcinoma may be largely attributed to the aggressive nature of the cancer and advanced disease at presentation. Though surgical resection has long been the standard of care for management of early stage disease, fewer than half of all patients presenting for treatment have surgically resectable cancer, and an even smaller proportion can undergo surgery with curative intent $[2,3]$. Studies and clinical practice have demonstrated the effectiveness of esophagectomy, though its benefits are more limited with advanced carcinoma [4]. A 2009 study of patients undergoing esophagectomy for stage I-III esophageal cancer showed five-year survival rates of less than $50 \%$ for all but those with stage I disease [5]. Persistently poor patient outcomes have driven the use of chemotherapy and/ or radiation in the adjuvant or neoadjuvant setting. Previous studies suggest that chemoradiation may lead to similar or greater outcomes than surgery alone, but results remain controversial [6].

Although more recent phase II and III studies have suggested that multimodal treatment may improve survival by $10-15 \%$, data supporting the survival benefits of trimodality therapy has been mixed [7-10]. In addition there is limited evidence that this data can be applied practically in real life practice. Evidence of significantly improved survival with a 
trimodality approach has been shown, with the 2006 CALGB 9781 trial of 56 patients demonstrating an improvement of more than $50 \%$ in overall survival rates when compared with surgery alone [9]. Similarly, the CROSS study published in 2012 demonstrated significantly increased survival with neoadjuvant chemoradiation compared with surgery alone (49.4 months vs. 24 months). However, the EORTC clinical trial in 1997 and the TROG trial of 2005 showed no difference in survival with trimodality therapy when compared to surgical resection [7]. Several other studies investigating multimodal treatment have excluded patients with stage 3 disease or been limited by small sample size or a lack of statistical significance [9]. As a result, the benefits of trimodality therapy have conflicting evidence, and concerns remain regarding both the potential toxicities posed by chemoradiation and what may represent an increased risk of postoperative morbidity with the addition of neoadjuvant therapy $[11,12]$. Lastly, in addition to these mixed studies, there is limited existing data on real world practice of efficacy or in terms of morbidity and mortality.

The existing literature on esophageal cancer delineates a multitude of potential treatment strategies but a lack of consensus regarding optimal management of advanced disease, and there remain questions as to when trimodality therapy should play a role. In reviewing existing literature, the majority of prior studies assessing neoadjuvant or adjuvant chemoradiation have primarily focused on early stage esophageal carcinoma in patients who were able to undergo optimal surgical resection. In addition, these analyses have typically not stratified patients by disease stage [8]. Furthermore, most previous studies have compared the outcomes of trimodality therapy or neoadjuvant chemotherapy or radiation with surgery alone. No previous esophageal cancer study has compared three different treatment regimens with a follow-up up to 21 years.

In this review, we assess the survival and treatmentrelated toxicity of stage II and III esophageal cancer patients, with the hypothesis that trimodality therapy may improve survival when compared with surgery alone, chemotherapy and surgery, or chemoradiation alone. The overall aim was to analyze three different approaches for the management of later stage esophageal cancer for which a standard of care has not been well-established.

\section{Methods \& analysis}

\section{Patient data collection}

IRB approval was granted by the University of Washington for this study. Data was gathered from a list of patients who presented to the University of Washington Medical Center (UWMC) or the Seattle Cancer Care Alliance (SCCA) in Seattle, WA for management of esophageal cancer between 1995 and 2016. After review of each patient's medical record to determine eligibility, a sample of 358 individuals was selected. Eligible patients had a diagnosis of stage II or stage III esophageal adenocarcinoma or squamous cell carcinoma and received treatment at UWMC or the SCCA involving surgery, chemotherapy, radiotherapy, or a combination of those therapies. Treatment decisions in most cases involved multidisplinary discussion, such as through tumor board discussion, involving radiation oncologists, general surgeons, and medical oncologists.

Patient information collected from medical records included age, gender, race, cancer histologic subtype, cancer stage at the time of treatment initiation, disease-free date if reached, date and location of cancer recurrence if applicable, treatment modality, pre-existing comorbidities, treatment toxicities, mortality status, and estimated cause of death. The date of death was gathered from either the Social Security Death Index or medical records. Cancer staging for each patient was reviewed in accordance with the $7^{\text {th }}$ edition of the AJCC Cancer Staging Manual. Patient comorbidities were quantified using the Charlson Comorbidity Index, and toxicities graded from 1-5 in accordance with the Common Terminology Criteria for Adverse Events (CTCAE) version 4.

\section{Classification}

After data extraction, eligible patients were stratified by both stage of esophageal carcinoma and type of treatment received. Patients were divided into 3 treatment groups: trimodality therapy (group 1, T), surgery alone (group 2, S), and chemoradiation alone (group 3, $\mathrm{CH}+\mathrm{R}$ ).

\section{Statistical analysis}

We were interested in several statistical measures in this study. Patients with stage II and III disease were analyzed separately as two groups, as well as among the three treatment groups. Kaplan Meier survival curves were constructed for each group and stage to estimate median overall survival. A subset of patients who became disease-free after treatment was considered for progression-free survival and comparison through the log-rank test. The time metric for progressionfree survival was defined to be the time from disease-free date until time of relapse, death, or loss to follow-up.

Cox Regression analysis was performed by treatment group and stage. Multivariate analysis was used to determine whether patient gender, ethnicity, age at diagnosis, histologic subtype, and treatment toxicity grade had significant effects on survival. Adjustment for medical comorbidities, histologic subtype, and the toxicity of each treatment plan was controlled for in multivariate analysis. Analysis was done on ethnicity as white vs. other.

\section{Outcomes}

The primary endpoint of this study was calculation of median overall and disease-free survival for each treatment group. We were also interested in survival differences between stage II and stage III patients. Secondary endpoints included assessment of treatment-related toxicity and the identification of other variables potentially having a significant impact on survival.

\section{Results}

\section{Patient characteristics}

The analysis included 358 patients encompassing 7 ethnic groups and an age range from 31-91. The sample was $79.9 \%$ 
male and predominantly Caucasian (74\%). The average age at diagnosis was 63.7 years for stage 2 patients and 62.6 years for the stage 3 group. $78.5 \%$ of patients had adenocarcinoma while $21.5 \%$ had squamous cell (Tables 1,2). Median follow-up time was 22 months (range 1-250 mos).

\section{Overall survival}

Survival by stage: The overall survival of stage II and stage III patients showed a similar trend (Figure 1). Stage 3 patients fared worse, particularly prior to the time point of 130 months $(\mathrm{HR}=1.428,95 \%$ CI 1.065-2.438, $\mathrm{p}=0.023)$.

Survival by treatment: The $\mathrm{T}$ group achieved the greatest median overall survival (42.8 months). The $\mathrm{CH}+\mathrm{R}$ group achieved the next best outcome at 21.5 months, while the $\mathrm{S}$ group had a median survival time of 19.3 months (Figure 2). We also estimated 2-year, 3-year, and 5-year survival probabilities for all groups. $\mathrm{T}$ patients achieved the greatest 2,3 , and 5 -year

Table 1: Patient Characteristics.

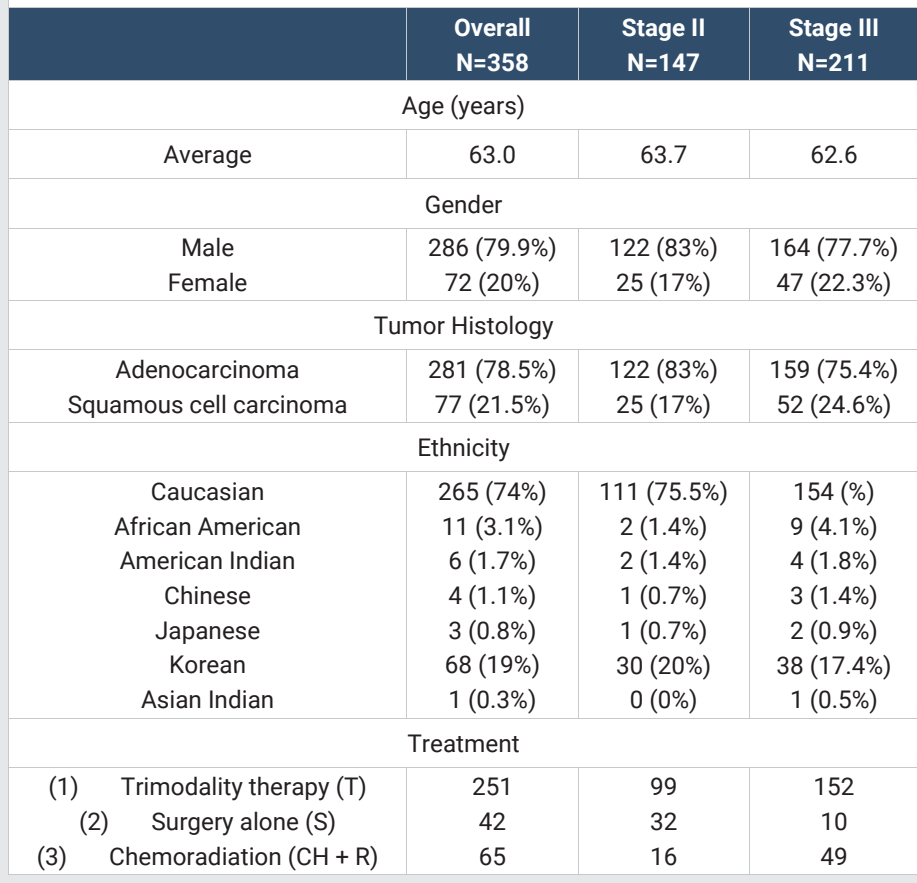

Table 2: Group Demographics.

\begin{tabular}{|c|c|c|c|}
\hline & $\mathbf{T}$ & $\mathbf{S}$ & $\mathbf{C H}+\mathbf{R}$ \\
\hline Age (average) & 62 & 68 & 65.5 \\
\hline Gender & $208(82.9 \%)$ & $33(78.6 \%)$ & $45(69.2 \%)$ \\
Male & $43(17.1 \%)$ & $9(21.4 \%)$ & $20(30.8 \%)$ \\
\hline Female & & & \\
\hline Tumor Histology & $211(84.1 \%)$ & $31(73.8 \%)$ & $38(58.5 \%)$ \\
Adenocarcinoma & $40(15.9 \%)$ & $11(26.2 \%)$ & $27(41.5 \%)$ \\
Squamous cell & & & \\
\hline Ethnicity & $18674.1 \%)$ & $28(66.7 \%)$ & $48(73.8 \%)$ \\
Caucasian & $5(2.0 \%)$ & $2(4.8 \%)$ & $4(6.2 \%)$ \\
African American & $3(1.2 \%)$ & $1(2.4 \%)$ & $2(3.1 \%)$ \\
American Indian & $2(0.8 \%)$ & $1(2.4 \%)$ & $1(1.5 \%)$ \\
Chinese & $2(0.8 \%)$ & $0(0 \%)$ & $1(1.5 \%)$ \\
Japanese & $52(20.7 \%)$ & $10(23.8 \%)$ & $8(12.3 \%)$ \\
Korean & $1(0.4 \%)$ & $0(0 \%)$ & $1(1.5 \%)$ \\
\hline Asian Indian & & & \\
\hline
\end{tabular}

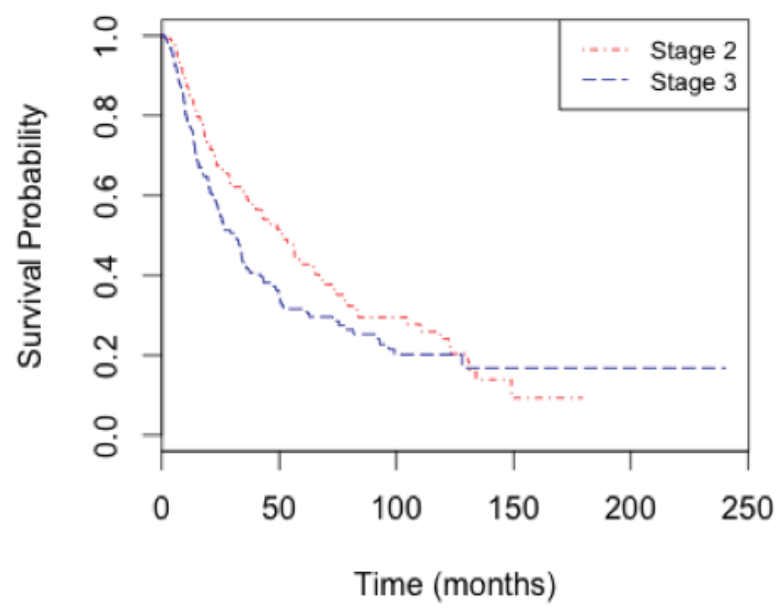

Figure 1: Survival by stage.

survival probabilities of $68.5 \%, 54.5 \%$, and $39.7 \%$, respectively (Table 3).

\section{Progression-free survival}

112 stage II and 137 stage III patients achieved diseasefree status after treatment. Of these, 89 stage II and 94 stage III patients had sufficient data for analysis of disease-free survival, specifically a date of diagnosis and date of diseasefree status. From this Kaplan-Meier curve, $\mathrm{CH}+\mathrm{R}$ patients seemed to outperform all other patient groups, with a median progression-free survival time of 21 months (95\% CI 3-30 mos). $\mathrm{T}$ patients achieved the second greatest median survival of 15.5 months ( $95 \%$ CI 12.5-25 mos), followed by S (13 mos, 95\% CI 3-41 mos) (Figure 3).

A log-rank test was performed to compare $\mathrm{T}$ survival to the other three patient groups. By this calculation, the progressionfree survival difference of $\mathrm{T}$ patients versus $\mathrm{S}(\mathrm{p}=0.18)$ and $\mathrm{CH}+$ $R$ patients $(p=0.56)$ was not significant.

\section{Cox regression analysis}

Cox regression analysis was performed to determine whether the following variables significantly influenced survival: treatment, gender, ethnicity, age at diagnosis, histologic subtype, comorbidity score, and treatment toxicity.

Groups $\mathrm{S}$ and $\mathrm{CH}+\mathrm{R}$ were compared with the $\mathrm{T}$ group to determine differences in mortality risk by treatment. The $S$ and $\mathrm{CH}+\mathrm{R}$ groups had hazard ratios of $2.341(\mathrm{p}<0.001)$ and 2.739 $(\mathrm{p}<0.001)$, respectively, indicating greater mortality risk than the $\mathrm{T}$ group.

In addition to the aforementioned influence of cancer stage and treatment on survival, this analysis revealed that patient gender ( $\mathrm{HR}=1.612, \mathrm{p}=0.024)$ and treatment toxicity $(\mathrm{HR}=1.341$, $\mathrm{p}=0.002)$ also significantly affected patient outcomes. Males achieved lower survival than females, and higher toxicity grades led to increased risk of treatment-related mortality. Age at diagnosis, histologic subtype, and comorbidity score did not significantly affect patient survival (Tables 4-6). 


\section{Regimens \& toxicities}

The specific chemotherapy regimens and radiation doses given to patients were similar across groups and stages. The most common chemotherapy combinations included carboplatin with docetaxel and capecitabine, cisplatin with 5-fluorouracil, cisplatin with irinotecan, and carboplatin with paclitaxel. $83.66 \%$ of patients received some form of platinum-based chemotherapy Most patients (91.7\%) received radiation doses between 44 and $60 \mathrm{~Gy}$, most commonly $50.4 \mathrm{~Gy}$ (64.52\%). The range of doses was 21 to $66 \mathrm{~Gy}$, though only one patient received each of these extreme doses.

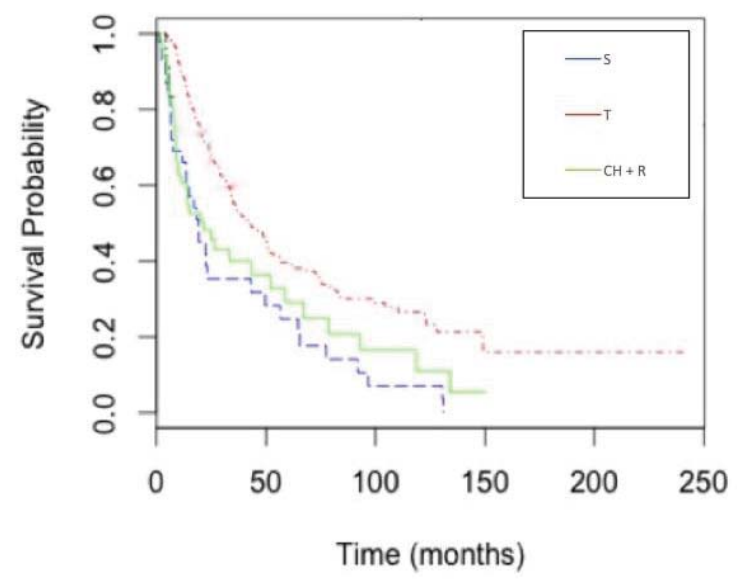

Figure 2: Survival by treatment.

Table 3: Survival Probabilities.

\begin{tabular}{|l|l|l|l|}
\hline Group & 2-year survival & 3-year survival & 5-year survival \\
\hline (1) T & 68.5\%(61.5-74.5\%) & $54.5 \%(46.8-61.5 \%)$ & $39.7 \%(31.9-47.3 \%)$ \\
\hline (2) S & $35.4 \%(19.8-51.4 \%)$ & $35.4 \%(19.8-51.4 \%)$ & $24.8 \%(11.4-40.7 \%)$ \\
\hline (3) CH + R & $48.2 \%(34.3-60.8 \%)$ & $40 \%(26.1-53.6 \%)$ & $29.1 \%(15.6-44 \%)$ \\
\hline
\end{tabular}

Progression-Free Survival

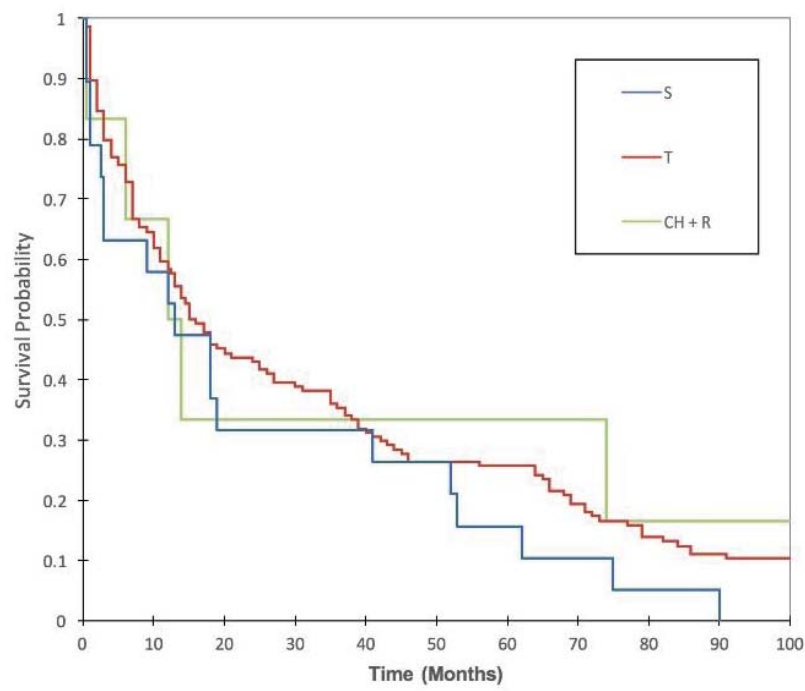

Figure 3: Progression-free survival.
Table 4: Cox analysis: T vs other regimens.

\begin{tabular}{|c|c|c|c|}
\hline Variable & Hazard ratio & p-value & Cl \\
\hline Group S & 2.341 & $<0.001$ & $1.526-3.591$ \\
\hline Group $\mathrm{CH}+\mathrm{R}$ & 2.739 & $<0.001$ & $1.801-4.165$ \\
\hline
\end{tabular}

Table 5: Cox analysis: other variables.

\begin{tabular}{|c|c|c|c|}
\hline Variable & Hazard ratio & p-value & $\mathbf{C l}$ \\
\hline Age at diagnosis & 1.008 & 0.308 & $0.993-1.024$ \\
\hline Male & 1.612 & 0.024 & $1.065-2.438$ \\
\hline Histology & 0.786 & 0.252 & $0.521-1.186$ \\
\hline Comorbidities & 0.950 & 0.264 & $0.869-1.039$ \\
\hline Toxicity score & 1.341 & 0.002 & $1.117-1.611$ \\
\hline
\end{tabular}

Table 6: Common toxicities.

\begin{tabular}{|c|c|c|c|}
\hline Common Toxicities & $\mathrm{T}$ & S & $\mathrm{CH}+\mathrm{R}$ \\
\hline $\begin{array}{l}\text { Pain } \\
\text { Grade } 1 \text { or } 2 \\
\text { Grade } 3 \text { or } 4\end{array}$ & $\begin{array}{c}63(25 \%) \\
112(44.6 \%)\end{array}$ & $\begin{array}{c}21(50 \%) \\
14(33.3 \%)\end{array}$ & $\begin{array}{c}15(23.1 \%) \\
3(4.6 \%)\end{array}$ \\
\hline $\begin{array}{l}\text { Pleural effusion } \\
\text { Grade } 1 \text { or } 2 \\
\text { Grade } 3 \text { or } 4\end{array}$ & $\begin{array}{l}58(23 \%) \\
9(3.6 \%)\end{array}$ & $\begin{array}{c}7(16.7 \%) \\
1(2.4 \%)\end{array}$ & $\begin{array}{c}2(3.1 \%) \\
0\end{array}$ \\
\hline $\begin{array}{c}\text { Fatigue } \\
\text { Grade } 1 \text { or } 2 \\
\text { Grade } 3 \text { or } 4\end{array}$ & $\begin{array}{c}38(15.1 \%) \\
2(0.08 \%)\end{array}$ & $\begin{array}{l}3(7.1 \%) \\
1(2.4 \%)\end{array}$ & $\begin{array}{c}10(15.4 \%) \\
1(1.5 \%)\end{array}$ \\
\hline $\begin{array}{l}\text { Arrhythmia } \\
\text { Grade } 1 \text { or } 2 \\
\text { Grade } 3 \text { or } 4\end{array}$ & $\begin{array}{c}40(15.9 \%) \\
0\end{array}$ & $\begin{array}{c}9(21.4 \%) \\
1(2.4 \%)\end{array}$ & $\begin{array}{l}0 \\
0\end{array}$ \\
\hline $\begin{array}{c}\text { Anorexia } \\
\text { Grade } 1 \text { or } 2 \\
\text { Grade } 3 \text { or } 4\end{array}$ & $\begin{array}{c}35(13.9 \%) \\
2(0.08 \%)\end{array}$ & $\begin{array}{c}6(14.3 \%) \\
1(2.4 \%)\end{array}$ & $\begin{array}{l}3(4.6 \%) \\
3(4.6 \%)\end{array}$ \\
\hline $\begin{array}{l}\text { Dysphagia } \\
\text { Grade } 1 \text { or } 2 \\
\text { Grade } 3 \text { or } 4\end{array}$ & $\begin{array}{c}23(9.2 \%) \\
4(1.6 \%)\end{array}$ & $\begin{array}{c}4(9.5 \%) \\
0\end{array}$ & $\begin{array}{c}9(13.8 \%) \\
2(3.1 \%)\end{array}$ \\
\hline $\begin{array}{l}\text { Esophagitis } \\
\text { Grade } 1 \text { or } 2 \\
\text { Grade } 3 \text { or } 4\end{array}$ & $\begin{array}{c}20(7.9 \%) \\
5(2.0 \%)\end{array}$ & $\begin{array}{l}2(4.8 \%) \\
2(4.8 \%)\end{array}$ & $\begin{array}{l}3(4.6 \%) \\
2(3.1 \%)\end{array}$ \\
\hline $\begin{array}{c}\text { Nausea } \\
\text { Grade } 1 \text { or } 2 \\
\text { Grade } 3 \text { or } 4\end{array}$ & $\begin{array}{c}19(7.6 \%) \\
5(2 \%)\end{array}$ & $\begin{array}{l}1(2.4 \%) \\
1(2.4 \%)\end{array}$ & $\begin{array}{c}7(10.8 \%) \\
0\end{array}$ \\
\hline $\begin{array}{c}\text { Esophageal fistula } \\
\text { Grade } 1 \text { or } 2 \\
\text { Grade } 3 \text { or } 4\end{array}$ & $\begin{array}{l}6(2.4 \%) \\
2(0.8 \%)\end{array}$ & $\begin{array}{l}1(4.8 \%) \\
1(4.8 \%)\end{array}$ & $\begin{array}{l}2(3.1 \%) \\
1(1.5 \%)\end{array}$ \\
\hline $\begin{array}{l}\text { Radiation pneumonitis } \\
\text { Grade } 1 \text { or } 2 \\
\text { Grade } 3 \text { or } 4\end{array}$ & $\begin{array}{c}19(7.5 \%) \\
0\end{array}$ & $\begin{array}{l}0 \\
0\end{array}$ & $\begin{array}{l}5(7.7 \%) \\
1(1.5 \%)\end{array}$ \\
\hline $\begin{array}{c}\text { Diarrhea } \\
\text { Grade } 1 \text { or } 2 \\
\text { Grade } 3 \text { or } 4\end{array}$ & $\begin{array}{c}22(8.8 \%) \\
0\end{array}$ & $\begin{array}{c}2(4.8 \%) \\
0\end{array}$ & $\begin{array}{l}1(1.5 \%) \\
2(3.1 \%)\end{array}$ \\
\hline $\begin{array}{l}\text { Vomiting } \\
\text { Grade } 1 \text { or } 2 \\
\text { Grade } 3 \text { or } 4\end{array}$ & $\begin{array}{c}15(6 \%) \\
2(0.08 \%)\end{array}$ & $\begin{array}{l}2(4.8 \%) \\
1(2.4 \%)\end{array}$ & $\begin{array}{l}3(4.6 \%) \\
2(3.1 \%)\end{array}$ \\
\hline $\begin{array}{l}\text { Anemia requiring } \\
\text { transfusion } \\
\text { Grade } 1 \text { or } 2 \\
\text { Grade } 3 \text { or } 4\end{array}$ & $\begin{array}{c}4(1.6 \%) \\
1(0.4)\end{array}$ & $\begin{array}{l}2(4.8 \%) \\
1(2.4 \%)\end{array}$ & $\begin{array}{c}2(3.1 \%) \\
0\end{array}$ \\
\hline
\end{tabular}

Overall, the majority of patients experienced some form of treatment-related toxicity. The most commonly reported side effects for all treatment modalities included post-operative pain $(63 \%)$, pleural effusion $(21.4 \%)$, fatigue $(15.4 \%)$, arrhythmia (14.6\%), anorexia (14.1\%), dysphagia (11.9\%) most

Citation: Christensen DM, Paulsson AK, Thind BS, Miller TT, Zeng J, et al. (2020) Long term follow-up of a large patient population with stage 2 and 3 esophageal cancer. J Surg Surgical Res 6(2): 110-115.DOI: https://dx.doi.org/10.17352/2455-2968.000108 
commonly secondary to esophagitis, nausea (9.2\%), diarrhea (7.6\%), and vomiting (6.8\%) (Table 6$)$.

Within the T group, the two most common toxicities were pain $(69.7 \%)$ and pleural effusion $(26.7 \%) .64 .9 \%$ of patients in this group experienced a toxicity of 3 or higher. In the $\mathrm{S}$ group, the most common adverse events were pain (83.3\%) and arrhythmia (23.8\%). $69 \%$ of $\mathrm{S}$ patients experienced a treatment-related toxicity of grade 3-5 (Table 7).

5 patients died due to treatment-related toxicity, which included 2 patients in the $\mathrm{T}$ group $(0.08 \%)$ and $3 \mathrm{~S}$ patients $(7.1 \%)$. Causes of death were gastrointestinal bleed and sepsis in the T group, and ARDS with hemothorax, CVA, and aspiration pneumonia in the 3 surgical patients.

Table 7: Treatment-related toxicity by grade.

\begin{tabular}{|c|c|c|c|}
\hline Toxicities & $\mathbf{T}$ & $\mathbf{S}$ & $\mathbf{C H}+\mathbf{R}$ \\
\hline Grade 0 & $6(2.4 \%)$ & $3(7.1 \%)$ & $6(9.2 \%)$ \\
Grade 1 & $24(9.6 \%)$ & 0 & $8(12.3 \%)$ \\
Grade 2 & $58(23.1 \%)$ & $10(23.8 \%)$ & $28(43.1 \%)$ \\
Grade 3 & $134(53.4 \%)$ & $24(57.1 \%)$ & $18(27.7 \%)$ \\
Grade 4 & $27(10.8 \%)$ & $2(4.8 \%)$ & $5(7.7 \%)$ \\
Grade 5 & $2(0.8 \%)$ & $3(7.1 \%)$ & 0 \\
\hline
\end{tabular}

\section{Discussion}

Though surgical resection has historically been the mainstay of treatment for esophageal cancer, a five-year survival rate of approximately $20 \%$ leaves room for improvement in patient management [9]. The results of this study suggest that the addition of chemotherapy and radiation leads to an almost doubling of overall survival compared with surgery alone.

Our data from a large sample of 358 patients and 21 years of institutional experience demonstrate significantly improved overall patient survival with trimodality therapy. Unlike previous studies, this analysis compared the outcomes and toxicities of trimodality therapy with surgery alone as well as with chemotherapy and surgery and chemoradiation alone. Furthermore, the 21-year duration of this retrospective study allowed us to assess survival up to a time point of nearly 250 months for some patients.

In our study population, the $\mathrm{T}$ group achieved the greatest median overall survival of 42.8 months. $\mathrm{CH}+\mathrm{R}$ patients achieved the next best overall outcome at 21.5 months followed by the $\mathrm{S}$ group with 19.8 months. The T group also achieved the greatest overall 2, 3, and 5-year survival estimates of $68.5 \%$, $54.5 \%$, and $39.7 \%$.

With respect to progression-free survival, $\mathrm{CH}+\mathrm{R}$ patients seemed to outperform the other treatment groups in our Kaplan-Meier analysis with a median disease-free survival of 21 months. This difference was not significant when compared with the $\mathrm{T}$ group, which achieved a median disease-free survival of 15.5 months $(p=0.56)$. We therefore suspect that this observation may be skewed by small sample size, and are not able to draw definitive conclusions regarding the effects of different therapies on progression-free survival as all differences were not significant when compared to $\mathrm{T}$ patients with the log rank test. Future studies may wish to investigate this further with a larger cohort of $\mathrm{CH}+\mathrm{R}$ patients.

In addition to improved survival, our analysis showed that trimodality therapy appears to be relatively well-tolerated by patients. The incidence and severity of treatment-related toxicity among $\mathrm{T}$ patients was similar when compared to the other treatment groups. Our data suggest that $\mathrm{CH}+\mathrm{R}$ patients may have experienced fewer therapy-related side effects overall, though the frequency and severity of adverse events was similar for all groups.

There were several demographic differences among the four groups that may have affected outcomes. As shown in Table 2, the $\mathrm{T}$ group had the lowest average age at diagnosis at 62 years, and the greatest proportion of adenocarcinomas (84.1\%). We did find that male gender is associated with a significantly higher mortality risk, and there was a greater proportion of females in the $\mathrm{CH}+\mathrm{R}$ group at $30.8 \%$. Future studies may wish to investigate these potential confounding effects further.

Overall, our analysis shows that trimodality therapy may lead to significantly improved overall survival without notably different toxicity than three other common treatment regimens. Additionally, we demonstrate that cancer stage expectedly impacts survival, with stage 3 patients achieving worse outcomes ( $\mathrm{HR}=1.428, \mathrm{p}=0.023)$. Our results also suggest that patient gender and toxicity score significantly affect outcome, with males and those with higher grade treatmentrelated toxicities possessing a higher mortality risk.

This data has practical results that support several recent clinical trials suggesting the efficacy of trimodality therapy with stage II and III esophageal cancer. The phase III CALGB 9781 trial published in 2008 demonstrated median survival of 4.48 years for trimodality therapy patients versus 1.79 years for surgery alone [8]. These results are in agreement with those found from our experience, but the trial was limited by poor accrual and its ultimate sample size of 56 patients. The CROSS trial of 2012, which randomized 368 patients to trimodality therapy or surgery alone, showed that trimodality therapy led to significantly greater survival (49.4 months versus 24.0 months) [8]. This trial included many patients with more advanced disease (clinical stage $\mathrm{T} 3$ or N1) and thus had a similar patient demographic to our analysis. However, the CROSS trial analysis did not stratify patients by disease stage and only compared two treatment regimens. More recently, multiple studies have reiterated the importance of multimodal management of esophageal cancer with locally advanced disease $[9,13-16]$. The question of definitive chemoradiation without surgery has been suggested to have similar outcomes to trimodality therapy with decreased surgical morbidity, particularly in poor surgical candidates with squamous cell histology. However, survival was only assessed up to 3 years, making it difficult to assess long term disease-free survival [10]. Thus, our study adds support to the existing literature but includes significant follow-up to better assess long-term outcomes. 
Despite significant results, this study did have several limitations. First, our analysis was retrospective in nature. Thus, there may be selection bias in our sample and, as previously mentioned, there were demographic differences of uncertain clinical significance between the four groups. For example, there was a high proportion of adenocarcinoma histology within our sample with some variation between groups. Additionally, treatment groups were not of similar size, with $251 \mathrm{~T}, 65 \mathrm{CH}+\mathrm{R}$, and $42 \mathrm{~S}$ patients. However, the disproportionate size of our trimodality group, larger than most previous studies, does add power to our results [4].

Though we did have a follow-up time of up to 250 months for patients, the duration of follow-up was not necessarily equal for all patients as we did include patients diagnosed with cancer as recently as 2015 . Additionally, patient mortality status was determined from medical records when possible but often obtained by the Social Security Death Index (SSDI). Since the SSDI does not make public deaths that occurred within the past two years, it is possible that some patients in our sample expired between June 2014 and June 2016 without our knowledge. Information gathered regarding patient treatments, demographics, and estimated cause of death are limited by the accuracy of the medical records utilized.

Finally, specific differences in treatment did exist within the four groups themselves with respect to chemotherapy regimens and radiation doses. Though the majority of patients received platinum-based combination chemotherapy (83.66\%) and a cumulative radiation dose of $50.4 \mathrm{~Gy}(64.52 \%)$, differences in therapy cycles and doses could have affected survival within groups. Future randomized controlled trials could control for these differences and assess treatment groups with a greater degree of standardization.

As the eighth most common cancer globally and the sixth leading cause of cancer mortality, esophageal cancer represents an important public health concern [1]. For patients presenting with more advanced disease for whom surgery is unlikely to be curative, outcomes may be greatly improved with adjuvant and neoadjuvant therapies in a multidisciplinary setting. Our data suggest that trimodality therapy may accord the greatest overall survival benefits to stage 2 and 3 esophageal cancer patients without significantly affecting the incidence and severity of treatment-related toxicities. Treatment modality, cancer stage, patient gender, and treatment toxicity appear to significantly impact patient survival.

Although selection of optimal treatment remains subject to clinical decision-making and individual patient characteristics, further objective data in the form of randomized controlled studies and retrospective studies are necessary to continue improving and standardizing the care of more advanced esophageal cancer.

\section{References}

1. Zhang Y (2013) Epidemiology of esophageal cancer. World J Gastroenterol 19: 5598-5606. Link: https://bit.ly/2Wp2Lz8

2. Almhanna K, Shridhar R, Meredith KL (2013) Neoadjuvant or adjuvant therapy for resectable esophageal cancer: is there a standard of care? Cancer Control 20: 89-96. Link: https://bit.ly/30fypQr

3. Burmeister B (2015) Role of radiotherapy in the pre-operative management of carcinoma of the esophagus. World $\mathrm{J}$ Gastrointest Oncol 7: 1-5. Link: https://bit.ly/30fr9nN

4. Malthaner R, Wong RK, Rumble RB, Zuraw L (2004) Neoadjuvant or adjuvan therapy for resectable esophageal cancer: a systematic review and metaanalysis. BMC Medicine 2: 35. Link: https://bit.ly/32pglq2

5. Rice TW, Rusch VW, Apperson-Hansen C (2009) Radiation therapy, chemoradiotherapy, neoadjuvant approaches, and postoperative adjuvan therapy for localized cancers of the esophagus. Disorders of the Esophagus 1.

6. Deng J, Wang C, Xiang M, Liu F, Liu Y, et al. (2014) Meta-analysis of postoperative efficacy in patients receiving chemoradiotherapy followed by surgery for resectable esophageal carcinoma. Diagnostic Pathology 9: 151 Link: https://bit.ly/2WjOAez

7. Courrech Staal EW, Aleman BM, Boot $H$, Velthuysen MLF, Tinteren $H$, et al. (2010) Systematic review of the benefits and risks of neoadjuvant chemoradiation for oesophageal cancer. British Journal of Surgery 10: 1482 1496. Link: https://bit.ly/2ZwLxS3

8. Ikebe M, Morita M, Yamamoto M, Toh Y (2016) Neoadjuvant therapy for advanced esophageal cancer: The impact on surgical management. Gen Thorac Cardiovasc Surg 64: 386-394. Link: https://bit.ly/3j7YQ38

9. Krug S, Michl P (2017) Esophageal Cancer: New Insights into a Heterogenous Disease. Digestion 95: 253-261. Link: https://bit.ly/2CBHnj5

10. Markar SR, Karthikesalingam A, Thrumurthy S, Low DE (2012) Volumeoutcome relationship in surgery for esophageal malignancy: systematic review and meta-analysis 2000-2011. J Gastrointest Surg 16: 1055-1063. Link: https://bit.ly/3h5bvSE

11. van Hagen $P$, Hulshof MC, van Lanschot JJ, Steyerberg EW, Henegouwen B, et al. (2012) Preoperative chemoradiotherapy for esophageal or junctional cancer. New England Journal of Medicine 22: 2074-2084. Link: https://bit.ly/20w62YY

12. Tepper J, Krasna MJ, Niedzwiecki D, Hollis D, Reed CE, et al. (2008) Phase III trial of trimodality therapy with cisplatin, fluorouracil, radiotherapy, and surgery compared with surgery alone for esophageal cancer: CALGB 9781. J Clin Oncol 26: 1086-1092. Link: https://bit.ly/3h5qKei

13. Jang R, Darling G, Wong R (2015) Multimodality Approaches for the Curative Treatment of Esophageal Cancer. J Natl Compr Canc Netw 13: 229-238. Link: https://bit.ly/20wE1R6

14. Greer SE, Goodney PP, Sutton JE, Birkmeyer JD (2005) Neoadjuvan chemoradiotherapy for esophageal carcinoma: A meta-analysis. Surgery 137 172-177. Link: https://bit.ly/3h2THYs

15. Shaikh T, Meyer JE, Horwitz EM (2017) Optimal Use of Combined Modality Therapy in the Treatment of Esophageal Cancer. Surg Oncol Clin N Am 26 405-429. Link: https://bit.ly/2B4vlZv

16. Sjoquist K, Burmeister BH, Smithers BM, Zalcberg JR, Simes JR, et al. (2011) Survival after neoadjuvant chemotherapy or chemoradiotherapy for resectable oesophageal carcinoma: an updated meta-analysis. Lancet Oncol 12: 681 692. Link: https://bit.ly/3ezbm8n

Copyright: @ 2020 Christensen DM, et al. This is an open-access article distributed under the terms of the Creative Commons Attribution License, which permits unrestricted use, distribution, and reproduction in any medium, provided the original author and source are credited. 